\title{
ANALISIS SETSUZOKUJOSHI DALAM KALIMAT BAHASA JEPANG
}

\author{
Amelia G.Y Sompotan
}

Universitas Negeri Manado, Indonesia

Email: ameliasompotan@unima.ac.id

\begin{abstract}
This study aims to find the similarities and differences between the three setsuzokujoshi in terms of usage, sentence structure and level of politeness in Japanese. The methodology used is the literature method, where the authors collect various definitions and explanations of the functions and sentence structures of setsuzokujoshi te, kara and node. In this descriptive study, the authors collected data from the textbook Minna No Nihongo I and II. From the three books, they tried to describe what functions were obtained from the results of the analysis of the example sentences found, then made conclusions on the data that had been analyzed. This study reveals that the function of kara (50\%) is often used for reasons that indicate a strong will, such as orders, the basis for providing advice on other things. Based on the results of data analysis, it can be concluded that setsuzokujoshi has various meanings and functions. Kara is subjective, therefore it can be linked with sentences that express personal thoughts. The kara function is often used for reasons that indicate strong will, such as commands, as well as in providing advice on other matters. Setsuzokujoshi kara is heavily influenced by the speaker's personal thoughts or judgments so it is said that kara is subjective in conveying reasons. Whereas the particles de and Setsuzokujoshi Node are used to express the causes of events or situations that are objective without being influenced by personal opinions or views, nodes are objective, cannot be used in conjunction with sentences in the form of personal decisions or wishes.
\end{abstract}

Keywords: cause and effect; setsuzokujoshi; kara; node
Abstract
Penelitian ini bertujuan untuk mencari persamaan dan perbedaan ketiga setsuzokujoshi tersebut dari segi penggunaan, struktur kalimat dan tingkat kesopanan dalam berbahasa Jepang. Metodologi yang digunakan yaitu metode kepustakaan, dimana penulis mengumpulkan berbagai definisi dan penjelasan mengenai fungsi dan struktur kalimat dari setsuzokujoshi te, kara dan node. Dalam penelitian deskriptif ini penulis mengumpulkan data dari buku ajar Minna No Nihongo I dan II Dari ketiga buku tersebut mencoba menggambarkan apa saja fungsi yang didapat dari hasil analisis contoh kalimat yang ditemukan, kemudian membuat kesimpulan atas data yang sudah dianalisis. Penelitian ini mengungkapkan bahwa fungsi kara $(50 \%)$ sering digunakan dalam alasan yang menunjukkan kemauan yang kuat seperti perintah, dasar dalam memberikan saran terhadap hal lain. Berdasarkan hasil analisis data, dapat disimpulkan bahwa setsuzokujoshi memiliki makna dan fungsi yang beragam. Kara bersifat subjektif, oleh karena itu dapat disambungkan dengan

$\begin{array}{ll}\text { How to cite: } & \text { Sompotan, Amelia G.Y (2021) Analisis Setsuzokujoshi dalam Kalimat Bahasa Jepang. Syntax Literate. } \\ & \text { 6(5). http://dx.doi.org/10.36418/syntax-literate.v6i5.2725 } \\ \text { E-ISSN: } & \text { 2548-1398 } \\ \text { Published by: } & \text { Ridwan Institute }\end{array}$


kalimat yang mengungkapkan pemikiran pribadi. fungsi kara sering digunakan dalam alasan yang menunjukkan kemauan yang kuat seperti perintah, juga dalam memberikan saran terhadap hal lain. Setsuzokujoshi kara banyak dipengaruhi oleh pemikiran atau penilaian pribadi pembicara maka dikatakan kara bersifat subjektif dalam menyampaikan alasan. Sedangkan partikel de dan Setsuzokujoshi Node digunakan untuk mengutarakan sebab dari peristiwa atau situasi yang bersifat objektif tanpa dipengaruhi oleh pendapat atau pandangan pribadi node bersifat objektif, tidak bisa digunakan bersamaan dengan kalimat yang berupa keputusan atau kemauan pribadi.

Kata Kunci: partikel; sebab akibat; setsuzokujoshi; kara; node

\section{Pendahuluan}

Memasuki era globalisasi, Indonesia menjadi melting pot bagi masyarakat dari berbagai negara dengan latar belakang bahasa dan budaya yang berbeda. Namun, masih terdapat beberapa kelemahan dari sumber daya manusia Indonesia, terutama penguasaan Bahasa (Munadzdzofah, 2018). Dalam kehidupan manusia dituntut untuk mengungkapkan pikiran dan perasaannya melalui bahasa. Tidak dapat dipungkiri bahwa bahasa merupakan salah satu sarana penting untuk tujuan tersebut. Dalam berbahasa ada bermacam-macam ungkapan yang digunakan. Berdasarkan gramatikal pembentukan kalimat, bahasa Jepang terdiri dari meishi (nomina), doushi (verba), keiyoushi (adjektiva), jodoushi (verba bantu), joshi (kata bantu) setsuzokushi (kata sambung), fukushi (kata keterangan), dan kandoushi (kata seru). Kata bantu mempunyai peranan penting dalam kalimat. Kata bantu atau biasa disebut dengan partikel atau joshi. Menurut Kawashima dalam (Masrokhah, 2019) A particles in the Japanese language follows a word to show its relationship to other words in sentence, and/or give that word a particular meaning or nuance. Kata bantu dalam bahasa Jepang jumlahnya jauh lebih banyak dibanding dengan bahasa Indonesia maupun bahasa Inggris. Makna dan fungsinya yang beragam, menjadikan masalah yang sangat berarti bagi mahasiswa dalam memahami kalimat, baik kalimat sederhana maupun kalimat yang panjang.

Dari berbagai macam jenis joshi terdapat salah satu macam joshi yaitu setsuzokujoshi. Hirai dalam (Sudjianto, 2004) menyatakan bahwa setsuzokujoshi adalah Joshi yang termasuk setsuzokujoshi dipakai setelah yoogen (dooshi, i-keiyoshi, nakeiyooshi) atau setelah jodooshi untuk melanjutkan kata-kata yang ada sebelumnya terhadap kata-kata yang ada pada bagian berikutnya.

Dalam Bahasa Jepang untuk menyatakan ungkapan sebab akibat menggunakan berbagai macam partikel, yaitu partikel から、ので、で.

Contoh kalimat :

(1) あぶないから きかい にさわらないでください。

abunai kara kikai ni sawaranaide kudasai

(karena bahaya, jangan sentuh mesinnya) (Ogawa, 2000)

(2) 目がわるいので めがね を かけています。

Me ga waruinode megane wo kaketeimasu

(karena mata rusak, saya memakai kacamata) (Chandra, 2009)

(3) 地震 で ビルが たおれました。

jishin de biru ga taoremashita

(karena gempa bumi, gedung besar itu roboh) (Ogawa, 2000)

(4)きのうびょうきで 会社へ 行きませんでした。 
kinou byouki de kaisha e ikimasendeshita

(kemarin saya tidak pergi ke kantor karena sakit) (Sulistyawati, 2016)

Masalah yang ditemui dalam menggunakan partikel-partikel yang mengungkapkan sebab akibat, misalnya pada contoh kalimat berikut :

(5)*びょうきで学校を休みたいです。

byouki de gakkou wo yasumitaidesu

(karena sakit, saya tidak ingin masuk sekolah)

Dari kedua contoh di atas jika dilihat dari bentuk dan artinya sama, tapi pada kalimat nomor (5) tidak bisa menggunakan partikel で.

Dari contoh-contoh diatas dapat dilihat ada banyak partikel yang digunakan untuk mengungkapkan ungkapan sebab akibat dan alasan, juga perbedaan fungsi dalam menggunakan partikel yang menyatakan ungkapan sebab akibat maupun alasan. Karena ada banyaknya partikel yang digunakan, membuat pembelajar Bahasa Jepang mengalami kesulitan dalam membuat kalimat yang menyatakan ungkapan sebab akibat dan alasan. Perbedaan fungsi partikel yang menyatakan ungkapan sebab akibat dalam Bahasa Jepang yang akan penulis teliti dalam penelitian ini.

Teks (bunshoo) merupakan susunan dari kalimat (bun), yang kemudian disusun kembali menjadi sebuah alinea atau paragraf (bunsestu), dan juga merupakan komponen koheren terkecil. Dalam penulisan bahasa Jepang, biasanya tidak terdapat jeda dalam setiap kalimatnya. Ciri khas asli dalam kalimat yang saling menempel tersebut menjadikan konsep kata dalam bahasa Jepang menjadi agak berbeda dibandingkan dengan kalimat-kalimat dalam bahasa Indonesia. Definisi kata-kata disampaikan dengan semantik dan struktur kalimat. Kalimat mempunyai kata atau makna tersendiri, diikuti oleh sufiks, dan partikel-partikel untuk memodifikasi arti dalam kalimat tersebut dan mendesainnya secara grammatikal. Menurut (Rakian, 2020), di dalam sebuah kalimat terdapat dua macam kategori, yaitu：1. Jiritsugo「自立語」2. Fuzokugo「付属語」

Jiritsugo「自立語」terbagi lagi menjadi：1. Katsuyougo「活用語」， 2.

Doushi「動詞」 3. Keiyoushi「イ形容詞」4. Keiyoudoushi「形容動詞」5. Mukatsuyougo「無活用後」6. Meishi「名詞」7. Daimeshi「代名詞」8. Fukushi 「福祉」9. Setsuzokushi「接続詞」 10. Kandoushi「感動詞」

Untuk kelas kata fuzokugo, hanya terbagi ke dalam dua kelas kata, yaitu : 1 . Joshi「助詞 2. Jodoushi「助動詞」

Berdasarkan fungsinya joshi dapat dibagi menjadi empat macam, yaitu sebagai berikut (Hirai, 1982) :

1. Kakujoshi「格助詞」Joshi yang termasuk kakujoshi pada umumnya dipakai setelah nomina untuk menunjukkan hubungan antara nomina tersebut dengan kata lainnya. Joshi yang termasuk kelompok ini misalnya ga, no, o, ni, e, to, yori, kara, de, dan ya.

2. Setsuzokujoshi「接続助詞 Joshi yang termasuk setsuzokujoshi dipakai setelah yogen (dooshi, I keyoushi, na-keiyoushi) atau setelah jodooshi untuk melanjutkan kata-kata yang ada sebelumnya terhadap kata-kata yang ada pada bagian berikutnya. Joshi yang termasuk kelompok ini misalnya ba, to, keredomo, ga, kara, shi, temo(demo), te(de), nagara, tari(dari), noni, dan node.

3. Fukujoshi「副助詞」; Joshi yang termasuk fukujoshi dipakai setelah berbagai macam kata. Seperti kelas kata fukushi, fukujoshi berkaitan erat dengan bagian kata berikutnya. Joshi yang termasuk kelompok ini misalnya wa, mo, koso, sae, demo, shika, made, bakari, dake, hodo, kurai (gurai), nado, nari, yara, ka, dan zutsu. 
4. Shuujoshi「終助詞」; Pada umumnya dipakai setelah berbagai macam kata pada bagian akhir kalimat untuk menyatakan suatu pertanyaan, larangan, seruan, rasa haru, dan sebagainya. Joshi yang termasuk kelompok ini misalnya ka, kashira, na, naa, zo, tomo, yo, ne, wa, no, dan sa.

Pengertian ungkapan sebab akibat menurut Ki Ageng Suryomantaram adalah suatu ungkapan yang menyatakan suatu kelanjutan peristiwa yang satu dengan peristiwa yang lain yang berurutan. Peristiwa pertama yang mendahuluinya disebut sebab sedangkan peristiwa berikutnya disebut akibat. Jadi kesimpulannya menurut Ki Ageng. Demikian juga apabila kita melihat arti sebab akibat menurut (Roni, 2001) bahwa ungkapan sebab akibat adalah "ungkapan yang menyatakan suatu hal, menyebabkan sesuatu yang mengakibatkan terjadinya suatu kesudahan dari suatu kejadian, peristiwa atau perbuatan".

Dengan melihat pengertian-pengertian di atas maka penulis menyimpulkan bahwa ungkapan sebab akibat adalah "suatu ungkapan yang menyatakan gabungan dua peristiwa dimana peristiwa pertama disebut sebab yang menjadi alasan terjadinya peristiwa berikutnya yang disebut akibat".

Berdasarkan latar belakang yang telah diuraikan sebelumnya, maka dapat dirumuskan permasalahnnya menjadi Bagaimanakah fungsi dan penggunaan setsuzokushi で, からdan ので dalam kalimat bahasa Jepang? Tujuan penelitian ini untuk mendeskripsikan fungsi dan penggunaan setsuzokushi で, からdanので dalam kalimat bahasa Jepang sehingga dapat meminimalisir kesalahan penggunaan setsuzokushi で, からdan のでdalam kalimat bahasa Jepang. Adapun manfaat penelitian secara Teoretis dapat menambah pemahaman fungsi dan penggunaan setsuzokushi で, からdan ので dalam kalimat bahasa Jepang

\section{Metode Penelitian}

Metode yang digunakan dalam penelitian ini adalah metode deskriptif. Penelitian deskriptif merupakan metode penelitian yang berusaha menggambarkan dan menginterpretasi objek sesuai dengan apa adanya (Best, 1986). Dalam pengumpulan data peneliti menggunakan metode simak, Metode pengumpulan data ini diberi nama Metode Simak karena cara yang digunakan untuk memperoleh data dilakukan dengan menyimak penggunaan bahasa. Istilah menyimak disini tidak hanya berkaitan dengan penggunaan bahasa secara lisan, tetapi juga penggunaan bahasa secara tertulis (Mahsun, 2005). Analisis data dalam penelitian ini menggunakan metode padan intralingual. Metode padan intralingual adalah metode analisis dengan cara menghubungbandingkan unsur-unsur yang bersifat lingual (Mahsun, 2011).

Sumber Data dalam penelitian ini adalah berupa kalimat ataupun klausa bahasa Jepang yang mengungkapkan ungkapan makna sebab akibat dan alasan. Maka dari itu, dalam penelitian ini yang menjadi sumber data yaitu: (1) buku-buku bacaan, termasuk di dalamnya novel, komik, majalah, koran berbahasa Jepang dan buku-buku pelajaran Bahasa Jepang, (2) Internet dan (3) Transkrip dialog film berbahasa Jepang. 


\section{Hasil dan Pembahasan}

\section{A. Makna dan Fungsi ungkapan で yang menyatakan ungkapan sebab akibat.}

Menurut Japan foundation dalam buku ぶんぽうじょししょもんだい 1 ada beberapa penempatan partikel で dalam kedudukan bahasa, yang mengungkapkan ungkapan sebab akibat.

1. Ungkapan で yang disebabkan oleh gejala alam.

さぶろ君 は インフルエンザで学校をを休みました。

Saburokun wa infuruenza de gakkou wo yasumimashita.

Saburo tidak masuk sekolah karena influenza. (Chandra, 2009)

2. Ungkapan で yang disebabkan oleh fenomena sosial/masyarakat 交通 事故で 死にました。

Kōtsū jiko de shinimashita.

Telah mati karena kecelakaan lalu lintas. (Evergeen, 2019)

B. Makna dan Fungsi ungkapan から yang menyatakan ungkapan sebab akibat.

Berikut ini beberapa contoh ungkapan "kara" yang menyatakan ungkapan sebab akibat.

1. Diikuti ungkapan yang menyatakan perintah :

時間 が ない から 急いでください。

jikan ga nai kara isoide kudasai

Karena tidak ada waktu maka cepat-cepatlah. (Sato, Breaden, \& Funai, 2020)

2. Diikuti ungkapan yang menyatakan ajakan :

もう遅いから 帰りましょう。

mou osoi kara kaerimashou

Karena sudah larut, mari kita pulang.

C. Makna dan Fungsi ungkapan ので yang menyatakan ungkapan sebab akibat.

1. Ungkapan node dipakai setelah doshi (kata kerja), keiyoshi (kata sifat), meishi (kata benda).

Contoh :

雨 が降っている ので 子供 は 家の 中で 遊んでいます。

Ame ga fitteiru node kodomo wa ie no naka de asondeimasu.

Karena hujan, anak-anak bermain di dalam rumah.

日曜日な ので 遅く起きました。

Nichiyoubi na node osoku okimashita.

Karena hari minggu saya bangun siang.

2. Ungkapan node dipakai pada bentuk biasa tetapi untuk membuat kalimat lebih sopan.

Contoh :

用事 がある ので お先にしつれいします。

Youji ga aru node osaki ni shitsurei shimasu.

Karena ada urusan saya permisi duluan. 


\section{Perbedaan Partikel でdengan partikel から yang menyatakan hubungan sebab akibat.}

Menurut (Ogawa, 2000) dalam bukunya Minna No Nihongo II : Terjemahan dan Keterangan Tata Bahasa dituliskan bahwa Kata bantu で yang menyatakan ungkapan sebab akibat terdapat keterbatasan predikat antara partikel から dan partikel で, yaitu ungkapan yang mengandung keinginan tidak dapat menggunakan partikel で.

Contoh :

(1) * 病気で会社を休みたい。

(2) 病気 から 会社を休みたい。

Pada kalimat di atas, kalimat (1) bentuk keinginan tidak dapat menggunakan partikel で, karena pembicara menginginkan 'besok tidak masuk kantor', karena 'sakit'. Kata 'sakit; pada kalimat pertama seolah-olah disengaja oleh pembicara agar tidak masuk kantor keesokkan harinya. Maka dari itu, melihat kedudukan kata benda sebelum partikel で ( 病気 ) dan melihat bagian predikat yang mengikuti yaitu bentuk keinginan maka lebih tepat menggunakan partikel から.

"Kedududkan partikel で dalam mengungkapkan ungkapan sebab akibat lebih cenderung menunjukkan gejala alam, keadaan kehidupan, dan fenomena sosial masyarakat."

1. Perbedaan Partikel から dengan partikel ので yang menyatakan hubungan sebab akibat.

Baik partikel からmaupun partikel ので memiliki arti yang sama dalam Bahasa Indonesia.. Namun walaupun memiliki arti yang sama, di antara kedua partikel ini terdapat beberapa perbedaan dalam pemakaiannya (Sudjianto, 2000).

Tomita Takayuki membedakan partikel kara dan partikel node dengan pola kalimat sebagai berikut.

Sebagai contoh :

(1) Aさんはきょう病気な ので学校を休んでいます。

A-san wa kyou byoukina node gakkou wo yasundeimasu.

Hari ini sdra A tidak masuk sekolah karena sakit.

(2)私はあたまがいたい から早く帰ろうと思っていま。

Watashi wa atama ga itai kara hayaku kaerou to omotteimasu.

Karena sakit kepala, saya bermaksud cepat-cepat pulang.

Dari kalimat 1 di atas, kita dapat mengetahui bahwa alasan adanya suatu kenyataan bahwa saudara A 'tidak masuk sekolah' dikarenakan 'sakit'. Sedangkan dari kalimat ke 2, kita dapat mengetahui alasan 'watashi' yang 'bermaksud akan cepat pulang' dikarenakan 'sakit kepala'. Sebab-sebab atau alasan yang ada sebelum partikel node memungkinkan terjadinya suatu kenyataan yang berbentuk aktivitas atau keadaan yang dikemukakan sesudah partikel node. Sedangkan bagian kalimat sebelum partikel kara merupakan sebab-sebab atau alasan yang menyebabkan 
timbulnya bagian kalimat setelah partikel kara yang berbentuk keinginan, kemauan, pemikiran, gagasan, pendapat atau konsep pembicara.

Contoh kalimat :

(1)*家 から 送って 来ました から どうぞ。

Ie kara okutte kimashita kara douzo.

Karena ini datang dari rumah keluarga, silahkan.

(2) 家 から 送って 来ました ので どうぞ。

Ie kara okutte kimashita node douzo.

Pada kalimat di atas ini, pembicara menawarkan sesuatu kepada tamu yang telah dikirim dari rumah keluarga si pembicara. Pada kalimat nomor (1) yang menggunakan kara terdengar kasar atau tidak sopan. Menurut Seichi Makino dan Michi O Tsutsui Lebih baik menggunakan node agar terdengan lebih sopan kepada tamu.

“から[kara] and ので [node] are used similarly, but they are not always interchangeable. For example ので [node] sounds softer than から[kara]. ので [node] is more appropriate than $か ら[$ kara] in formal sentences and polite speech.”

"Partikel kara dan node digunakan dengan cara yg sama..tapi tidak selalu bisa ditukarkan. Sebagai contoh node lebih terdengar lembut dari pada kara. Partikel Node lebih cocok/sesuai untuk dipakai pada kalimat formal dan pidato-pidato resmi dibandingkan dengan partikel kara." (Maynard, 2011).

\section{Kesimpulan}

Setsuzokujoshi memiliki makna dan fungsi yang beragam. Kara bersifat subjektif, oleh karena itu dapat disambungkan dengan kalimat yang mengungkapkan pemikiran pribadi. Sedangkan partikel de dan node bersifat objektif, tidak bisa digunakan bersamaan dengan kalimat yang berupa keputusan atau kemauan pribadi.Perbedaan Fungsi Ungkapan ので, から、dan で yang menyatakan ungkapan Sebab Akibat.

Pertama, Ungkapan で; Kedudukan partikel で dalam mengungkapkan ungkapan sebab akibat lebih cenderung menunjukkan gejala alam, keadaan kehidupan, dan fenomena sosial masyarakat. Kedua, Ungkapan から;Ungkapan yang menggunakan partikel ini, alasan yang diberikan lebih secara subjektif, seperti ungkapan-ungkapan yang menyatakan bentuk pemikiran, bujukan atau saran, perintah, kemauan, dan sebagainya. Ketiga, Ungkapan ので; Pada ungkapan yang menggunakan partikel ini, alasan yang diberikan harus tepat, berdasarkan fakta dan secara objektif dapat diterima. 


\section{BIBLIOGRAFI}

Best, J. (1986). Research in Education. New Jersey: Englewood Cliff. Prentice Hall.

Chandra, T. (2009). Nihongo No Joshi. Jakarta: Evergreen Japanese Course. Google Scholar

Evergeen, Kursus Bahasa Jepang. (2019). Partikel DE で. Retrieved from http://kursusjepang-evergreen.com/index.php/partikel-bahasa-jepang/54-partikel-de

Hirai, Hidematsu. (1982). Recollections of assembling Tiselius' apparatus. SEIBUTSU Butsuri Kagaku, 26(3), 159-161. Google Scholar

Mahsun, M. S. (2005). Metode penelitian bahasa. Jakarta: PT Raja Grafindo Persada. Google Scholar

Mahsun, M. S. (2011). Metode penelitian bahasa: tahapan strategi, metode dan tekniknya. Jakarta: PT Raja Grafindo Persada.

Masrokhah, Yuni. (2019). Analisis Kesalahan Penggunaan Setsuzokujoshi pada Mahasiswa Semester III Tahun Ajaran 2018/2019 Program Studi Pendidikan Bahasa Jepang FKIP UHAMKA. Jurnal Bahasa Jepang Taiyou, 2(1), 52-67. Google Scholar

Maynard, Senko K. (2011). Tools and Resources. In Learning Japanese for Real (pp. 328-338). University of Hawaii Press. Google Scholar

Munadzdzofah, Ofah. (2018). Pentingnya Bahasa Inggris, China, dan Jepang Sebagai bahasa Komunikasi Bisnis di era Globalisasi. VOCATIO: Jurnal Ilmiah Ilmu Administrasi Dan Sekretari, 1(2), 58-73. Google Scholar

Ogawa, Iwao. (2000). Minna No Nihongo I \& II: Terjemahan dan Keterangan Tata Bahasa. Tokyo: 3A Corporation. Google Scholar

Rakian, Sandra. (2020). Penggunaan Multimedia Dalam Pembelajaran Bahasa Jepang Praktis Pada Karyawan Objek Wisata Sumaru Endo Kecamatan Remboken. Edupreneur: Jurnal Pengabdian Kepada Masyarakat Bidang Kewirausahaan, 3(1). Google Scholar

Roni, Gunawan. K. (2001). Kamus Lengkap Bahasa Indonesia. Jakarta.

Sato, Yuriko, Breaden, Jeremy, \& Funai, Takashi. (2020). Nihongo Gakkō: The Functions and Dysfunctions of Japanese Language Institutes in Japan. Japanese Studies, 40(3), 333-352. Google Scholar

Sudjianto. (2000). Gramatika Bahasa Jepang Modern seri B (Kesaint Blanc, Ed.). Jakarta. 
Sudjianto, Ahmad Dahidi. (2004). Pengantar linguistik bahasa jepang. Jakarta: Kesaint Blanc, 250. Google Scholar

Sulistyawati, Nanik. (2016). Pengaruh Profesionalisme Dan Motivasi Kerja Terhadap Kinerja Guru Dengan Lingkungan Kerja Sebagai Variabel Moderasi (Studi Pada Smp Negeri Se Kecamatan Boja Kabupaten Kendal). Dharma Ekonomi, 23(43). Google Scholar

\section{Copyright holder:}

Amelia G.Y Sompotan (2021)

First publication right:

Journal Syntax Literate

This article is licensed under:

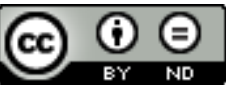

